\title{
Board Independence and Earnings Management: Evidence from Italy
}

\author{
Stella Lippolis ${ }^{1} \&$ Francesco Grimaldi ${ }^{2}$ \\ ${ }^{1}$ Ionian Department of Law, Economics and Environment, University of Bari Aldo Moro, Taranto, Italy \\ ${ }^{2}$ Department of Economics and Finance, University of Bari Aldo Moro, Bari, Italy \\ Correspondence: Francesco Grimaldi, Department of Economics and Finance, University of Bari Aldo Moro, \\ Largo Abbazia Santa Scolastica, Bari, 70124, Italy. E-mail: francesco.grimaldi1@uniba.it
}

Received: June 8, 2020

doi:10.5539/ijbm.v15n8p26
Accepted: June 24, 2020

Online Published: June 29, 2020

URL: https://doi.org/10.5539/ijbm.v15n8p26

\begin{abstract}
This research aims to analyze the relationship between the characteristics of the Board of Directors (BoD) and the effectiveness of the monitoring of earnings manipulation activities in family - controlled companies in Italy. In particular, specific hypotheses relating to the link between those aspects of the Board, that substantiate its independence, and earnings quality have been formulated to verify whether the mechanisms for monitoring management activity are less effective in these companies.

This study applies a univariate and multivariate methods on a sample of Italian listed company over the period 2014-2016. Earnings management is defined by the proxy of abnormal working capital accrual (AWCA) estimed model according to DeFond and Park (2001). Proxies for corporate governance mechanism are the board size, the level of board independence, the CEO non-duality and the interaction between the last two variables.

The research shows that independent directors are not, as in other contexts, a factor that contributes to earnings quality, in the same way that the separation of the offices of Chairman of the Board of Directors and Chief executive Officer (CEO) does not appear to be relevant to this end.

The study aims to provide a double contribution. First, the research represents one of the few studies concerning the Italian context with its peculiarities, taking into consideration the earnings management issue in companies with a high concentration of family ownership.

Secondly, this study aims to further stimulate the debate on the most effective features of structure and composition of the $\mathrm{BoD}$ in family-controlled companies: specifically, the conclusions could lead to a reconsideration of the validity of certain characters of the boards that defines independence.
\end{abstract}

Keywords: financial information, corporate governance, earnings management, family-controlled companies, board independence, Italy

\section{Introduction}

The relationship between financial information and corporate governance structures is a topic of great current interest and relevance. The theoretical contributions proposed by the literature have highlighted the role of corporate governance structures as mechanisms that influence external corporate information, with particular reference to the implementation of earnings management policies (EM). Specifically, the research carried out has investigated the quality and effectiveness of those corporate governance measures that make it possible to identify and limit earnings management activities and which refer mainly to public companies and the Anglo-Saxon capitalist context with its peculiarities in terms of highly developed financial markets, widely distributed ownership structure and a high degree of control contestability.

This relationship between the two phenomena, on the other hand, has not been sufficiently studied with reference to companies with a high concentration of family ownership, as it is particularly complex to evaluate the ways in which the combination of related agency problems can influence their accounting behavior and financial information practices.

It is necessary, in particular, to highlight how in the context of family-controlled companies, the agency problems linked to the separation of ownership and control appear to be less relevant than in non-family businesses. According to this approach, family members enjoy the advantages deriving from the natural alignment between the interests of the management and those of the shareholders, who share the common goal of creating value in 
order to guarantee the survival of the company in the long term (alignment effect). In this perspective, the control exercised by the family over management could favor the quality of financial information. Furthermore, families are considered to have a strong incentive to guarantee the quality of financial information because they are interested in preserving the name and reputation of the family (Wang, 2006).

However, other studies have shown that these companies can be characterized by different types of agency problems, namely those that arise between controlling shareholders and minority shareholders. This is thought to be mainly due to the entrenchment effect, i.e. the incentive that, in the case of a concentrated ownership structure, means that the controlling shareholder tends to become entrenched in his position, limiting the sharing of information and remuneration with minority shareholders. This prerogative then affects external information and, specifically, the ways in which the accounting behavior of these companies affects the "earnings quality" (Ali, Chen \& Radhakrishnan, 2007).

In light of these considerations and the lack of unequivocal results in previous empirical research, it is clear that an investigation into the ways in which the combination of the aforementioned agency problems influences the level of EM in family-controlled companies remains an issue that needs to be evaluated empirically.

The object of this study is to analyze the relationship between the characteristics of the Board and the effectiveness of the monitoring of earnings manipulation activities in family - controlled companies in Italy. In particular, specific hypotheses relating to the link between those aspects of the Board, that substantiate its independence, and earnings quality have been formulated, in order to verify whether the mechanisms for monitoring management activity are less effective in this type of companies.

Specifically, the study, using Italian companies listed in the 2014-2016 period as an analysis sample, investigates the relationship between EM and the characteristics of the Board, such as the percentage of independent directors and the absence of the so-called "duality of the CEO". With reference to each of the characteristics highlighted, general hypotheses have been formulated, i.e. referring to the whole sample of listed companies analyzed, and specific hypotheses, with particular reference to listed companies with family control to shed light on the question of whether board independence leads to constraints on earnings manipulation.

The survey shows that independent directors are not, as in other contexts, a factor that contributes to earnings quality, in the same way that the separation of the offices of Chairman of the $\mathrm{BoD}$ and Chief executive officer (CEO) does not appear to be relevant to this end. In particular, the results suggest that the presence of the family limits the board effectiveness in monitoring the earnings management practices.

Regarding the potential implications, the study aims to provide a double contribution. First, the research represents one of the few studies concerning the Italian context with its peculiarities, taking into particular consideration the earnings management issue in companies with a high concentration of family ownership, characterized by different type of agency problems.

Secondly, this study aims to further stimulate the debate on the most effective features of structure and composition of the $\mathrm{BoD}$ in family-controlled companies: specifically, the conclusions could lead to a reconsideration of the validity of certain characters of the boards that defines independence, when referred to these companies.

The paper is structured as follows. We summarize the most significant international literature on the subject and we propose general hypotheses and sub-hypotheses in section 2 . The methodology employed, the variables analysed and the empirical model proposed to test the hypotheses are described in section 3 . The results of the analysis and the discussion are presented in section 4 . Section 5 concludes the paper, outlining implications and suggesting possible future lines of research.

\section{Literature Review and Hypotheses}

\subsection{Corporate Governance and Earnings Management Policies: A Review of the Literature}

As previously pointed out, the literature does not agree in identifying the nature of the relationship that links corporate governance structures to the quality of financial information. It is possible to state that the investigation into this link has been dealt with mainly by examining two distinct groups of corporate governance variables, the first group can be traced back to the characteristics of the Board of Directors, and the second group attributable to the ownership structure.

In the first group of studies, the investigation objectives have mainly concerned the composition of the Board of Directors and the audit committee.

These investigations have mainly examined the Anglo-Saxon capitalist context and, in the wake of the positive 
accounting theory, have favored the use of models based on the agency theory (Watts \& Zimmermann, 1978). Obviously, the adoption of this approach has directed the observations of scholars to the factors and circumstances in which the control mechanisms are strengthened, elements identified in the structure and composition of the Board of Directors.

With reference to the presence of independent directors, in particular, the empirical evidence gives rise to results of a different nature.

In fact, there are studies that show that the presence of independent directors has a significant impact in terms of a reduction in earnings management; in line with the assumptions of the agency theory, therefore, the monitoring role they play to protect investors is thought to be reflected in the reliability of the financial statements (Beasley, 1996; Dechow, Sloan \& Sweeney, 1996). A similar result comes from a subsequent study by Klein which refers to the percentage of independent directors present in the audit committee, identifying a significant difference between audit committees made up entirely of independent directors and those, on the other hand, in which only half of the members are independent directors (Klein, 2002).

However, it should be noted that these studies refer to US companies, public companies with a broad shareholder base. Studies that address boards of directors of companies characterized by concentrated ownership, on the other hand, do not show clear results regarding the link between the independence of the board and earnings management policies.

In this regard it is appropriate to analyze the contribution of Park and Shin (2004) which concerns Canadian listed companies and which, while recording the presence of accounting practices - in the management of Accruals - aimed at achieving performance objectives, does not identify any relationship between them and the percentage of independent directors. This study is significant because of the peculiar characteristics of the capital market in Canada, which has developed in the same way as the US market, but which is characterized by highly concentrated companies with a high degree of legislative protection of minority shareholders (Park \& Shin, 2004).

A similar conclusion is reached by a recent study that analyzes a sample of companies listed in the Latin-American context, mainly family owned. In these companies, in fact, the role of external directors in reducing earnings management practices was found to be very limited. (Gonzalez \& Garcia-Meca, 2014).

Another area investigated by international studies concerns the correlation between CEO duality - when the same person is both CEO and Chairman of the Board - and earnings management practices. Even this slant of investigation has led to conflicting results highlighting, in some cases, the lack of a link between the two aspects (Kao \& Chen, 2004), and in others, instead, the existence of this link, in the sense that the companies in which there are earnings management practices very often have the same person holding the two offices (Dechow, Richardson \& Tuna, 2003).

As mentioned above, the studies aimed at detecting the influence of corporate governance on earnings management practices have addressed, in addition to the research trajectory mentioned thus far, also a second direction, this time characterized by the identification of the ownership structure as an observed variable. In essence, these studies have shown that, despite the diversity of institutional environments, the ownership structure has a significant impact on EM and, therefore, on the earnings quality.

Warfield, Wild J.J. and Wild K.L., for example, argue that a significant participation of managers in share ownership means that they have less incentive to manipulate accounting information (Warfield, J.J. Wild, \& K.L. Wild, 1995). Arriving at the same conclusions, but in a different context, is a study that focuses on Portuguese listed companies and claims that the participation of managers in ownership and equity concentration improves the quality of the results of the financial statements (Alves, 2012).

A recent study concerning listed companies in Germany in the period 1998-2008 - applying the socio-emotional wealth (SEW) perspective - highlighted how in this context family-controlled companies, compared to those that are not family owned, do not use earnings management strategies based on managing the timing of real operations (real earnings management or REM) as much as the accrual-based earnings management (ABEM) (Achleitner, Fichtl, Kaserer, \& Siciliano, 2014).

The theoretical contributions proposed by the international literature on the subject have highlighted the nature of those governance structures that make it possible to identify and limit earnings management activity. In the following, instead, we will illustrate the research concerning the companies listed in Italy, with particular reference to family owned ones.

The main contribution of Tiscini and Di Donato (2008) was to verify the ways in which family ownership and 
corporate governance can influence earnings quality. After having highlighted how the international literature gives an account of the two possible and opposite effects deriving from family property - the alignment effect and the entrenchment effect - the study hypothesizes that the impact of family ownership on earnings quality depends on the actual attitude of the family towards corporate governance mechanisms, since these reflect family incentives for a good reputation and responsibility. In the study, the governance mechanisms analyzed were mainly expressed by parameters such as the size of the board, the independence of the directors and the structure of the responsibilities within the board. The results obtained from the study confirmed the positive contribution of family directors to the role of monitoring top management and, consequently, the favorable effects on the alignment of interests and on the reduction of agency costs. CEO Duality, on the other hand, presented a negative correlation with earnings quality - albeit not with a very high significance - consistent with the explanation that the accumulation of offices represents a sign of "entrenchment" on the part of top management. With reference, instead, to the relationship between the quality of earnings and the presence of independent directors, the empirical survey identified a negative correlation between the two phenomena.

Again, with reference to the methods by which the characteristic ownership structure of listed family-owned companies influences accounting information, the empirical research of Cascino, Pugliese, Mussolino and Sansone should be noted. This research found that family businesses show, on average, a higher quality of accounting information than non-family owned businesses (Cascino, Pugliese, Mussolino \& Sansone, 2010). The "determinants" of accounting quality between family and non-family owned businesses would seem, then, to be different: in the former, the quality of the accounting information is positively associated with the independence of the Board of Directors and negatively in the presence of institutional investors in the property; in the latter, instead, the presence of institutional investors has a positive effect.

A subsequent investigation aimed to analyze, instead, the "subsample" of listed companies subject to family control, analyzing those features of the Board that should increase their independence and, consequently, their ability to control the activity of managers, i.e. the presence of independent directors and the absence of CEO duality. The authors pointed out that in Italian listed companies with family control these monitoring mechanisms are less effective (Prencipe \& Bar-Yosef, 2011). The percentage of independent members seems, in fact, to have a lesser effect in limiting earnings management policies in family owned companies than in non-family owned companies. With reference to the lack of coincidence of the positions of CEO and Chairman of the Board of Directors, this characteristic also seems to have less effectiveness in reducing accounting manipulations, but apparently only in the case in which the CEO is a member of the family of reference. These results seem to be in line with the theory that in family-controlled companies the Board - and the independent directors themselves - collude with the reference family. This "collusion" does not necessarily imply the existence of opportunistic behavior, but could indicate the trust that the members of the board have for the family, and, therefore, a lower level of monitoring activity on the process of accounting information production.

Another study that analyzes the link between corporate governance and earnings management in our country is the one by Marra which analyzed the relationship between the board's monitoring activity and the policies of earnings management in the Italian context in the period following the introduction of the IFRS (Marra, 2013). This work showed that as the number of independent directors increases there is an improvement in the quality of profits. The separation between the Chairman of the Board and the Chief Executive Officer, on the other hand, does not seem to be relevant.

Finally, a 2015 study, using the listed companies in the 2010-2012 period as a sample, investigated the relationship between the attribute of family company and the use of earnings management practices. The results suggested that these practices are used less in family-controlled listed companies. With regard to the Board's ability to act as a safeguard for the quality of financial information, the survey shows that independent directors do not represent a factor contributing to earnings quality, just as CEO duality does not appear to be relevant (Lippolis \& Grimaldi, 2015).

The review reported thus far highlights how the research conducted up to this time has given rise to results that are not always consistent and, moreover, how few studies have dealt with these topics in the Italian business context, where the reference model is that of the family business, even in the context of listed companies, and financial markets are less extensive and tend to be less efficient. Not being able, therefore, to extend to Italian companies the results obtained from surveys conducted in different contexts, there is a need for a specific analysis of Italian capitalist context within which to verify if and how the concentration of family ownership structures may constitute a limit to the evolution of the governance structure towards the acquisition of those characteristics, which can abstractly improve their ability to ensure the quality of financial information. 


\subsection{The Italian Capitalist System}

The Italian capitalist system presents specific characteristics that make it unique and difficult to link to international models univocally (Melis, 1999; Grimaldi \& Lippolis, 2019; Zattoni, 2019).

These characteristics can be identified in the existence of listed companies with a high concentration of ownership, often of a family nature, and in the consequent lack of a developed market for corporate control (Corbetta, 1995; Tiscini \& Di Donato, 2008); a high level of public intervention in the national economy and a passive attitude on the part of institutional investors are further dimensions that make the national corporate governance system unique (Barca, 1996; Melis, 2000).

In particular, it is necessary to point out the significant presence of listed companies with family control, whose controlling shareholders are members of the same family, or members of several families linked by family ties (Tiscini, 2008; Magli \& Nobolo, 2013; Consob, 2018).

Beyond the various possible definitions and the relative methods of measuring the "family business" phenomenon, it is worth noting that in this phenomenon the literature has highlighted the natural alignment between the interests of management and those of shareholders as subjects that share the goal of creating value to ensure the survival of the company in the long run (the so-called alignment effect) (Wang, 2006). Therefore, the agency problems linked to the separation between ownership and control are less relevant, while it is more likely that these companies be characterized by a different type of agency problem, namely the type that arise between controlling shareholders and minority shareholders (Ali et al., 2007): the so-called "entrenchment effect", i.e. the incentive that, in the case of a concentrated ownership structure, makes the controlling shareholder tend to become entrenched in his position, and to limit the sharing of information and remuneration with minority shareholders (Schulze, Lukatkin, Dino, \& Buchholz, 2001).

These ownership structures prevalent in Italian listed companies inevitably affect the functions of the Board of Directors, both with reference to the control function and with reference to the strategic function. The need for top management control is felt less, given the frequent overlap between managers and reference shareholders, while the strategic function is removed from the Board and delegated to the executive committee, or to the top management.

Notwithstanding this scenario, starting in the late 1990s, legislative measures to protect minorities and the introduction of the self-regulatory Code of Corporate governance for listed companies contributed to changing the structure and composition of boards.

In particular, the Italian Stock Exchange Code deems it necessary for non-executive directors to exercise - in number, competence and authority - a "significant weight", with the hope, in more general terms, that an adequate number of them will be independent (Corporate Governance Code of the Italian Stock Exchange).

As regards the independence of the directors - a requirement on which, as is known, the Board must express itself - the Code provides applicative criteria, which are not mandatory, necessary for the evaluation of the same. These criteria are related to the absence of significant economic relations with the company and the absence of personal relations. In particular, the indications contained in the Italian Stock Exchange Code highlight the independence of the controlling shareholders or the shareholders that exercise a significant influence.

With regard to the configuration of the leadership structure according to the agency theory, a dual structure, i.e. in which the CEO and the Chairman of the Board are the same subject, can interfere with the primary function of the board as a control tool to protect shareholders' interests (Jensen, 1993). In this regard, this study could not ignore the indications that, about this topic, come from the regulatory context in force in Italy. In fact, the scheme based on the separation of roles is preferred in the Corporate Governance Code, and the most recent version of the Code explicitly refers to this choice as necessary and appropriate.

\subsection{Hypotheses}

\subsubsection{Independent Directors and Earnings Management Policies}

As already amply highlighted in the analysis of the literature on the subject, the empirical evidence on the relationship between the independence of directors and practices of manipulation of profits gives rise to varying results.

In fact, there are studies that show that the presence of independent directors has a significant impact in terms of reduction of earnings management and accounting fraud, especially with reference to public companies (Beasley, 1996). Research on boards of directors of companies characterized by concentrated ownership, on the other hand, does not show such definite results. 
In particular, the empirical evidence concerning listed companies in Italy gave rise to conflicting results. While some studies have shown that as the number of independent directors increases, there is an improvement in the quality of profits (Di Donato, 2012; Marra, Mazzola \& Prencipe, 2011; Marra, 2013), others identify a negative correlation between the two phenomena (Tiscini \& Di Donato, 2008) or, indeed, no relationship (Lippolis \& Grimaldi, 2015).

In light of the above, it is noted that the relationship between the percentage of independent directors and the amount of earnings management practices requires further research. Therefore, this study considers the following general hypothesis:

H1: Earnings management is negatively correlated to the percentage of independent directors on the Board of Directors.

Specifically analyzing Italian listed companies with family control, recent studies have shown that the percentage of independent members seems to have a lesser effect on limiting earnings management policies than it does in non-family owned companies (Tiscini \& Di Donato, 2008). In family-controlled companies, the process of selecting the top management and members of the Board, in fact, seems to be based on personal ties and, therefore, even if they are formally independent, the board members tend to have implicit connections with the reference family (Prencipe \& Bar-Yosef, 2011).

The following sub-hypothesis was therefore considered: The percentage of independent Directors on the Board has a weaker effect on the magnitude of earnings in family-controlled listed companies than in the whole sample of listed companies.

\subsubsection{CEO Duality and Earnings Management Policies}

It was also observed that the studies suggest contrasting perspectives about the configuration of the leadership structure.

According to part of the literature, in fact, the dual structure can interfere with the function of the board as a control tool to protect shareholders' interests (Jensen, 1993). The overlap between the role of CEO and that of Chairman was, in fact, seen to reduce the level of accountability of the Board towards shareholders, allowing Top management team members greater discretion in making decisions that maximize their own interests.

Strategic management theories, on the other hand, offer a different interpretation of this duality since a unified leadership could be an essential prerequisite in strategic change processes.

With specific reference to the relationship between the duality of the CEO and earnings management, the national and international literature has highlighted, in some cases, a lack of connection between the two aspects (Kao \& Chen, 2004; Xie, Davidson \& DaDalt, 2003; Marra, 2013; Lippolis \& Grimaldi 2015) and in others, instead, the existence of this bond, in the sense that companies in which earnings management practices are present, very often have CEO duality (Dechow, Sloan \& Sweeney, 1995).

Therefore, the following general hypothesis is considered in this study:

H2: Earnings management is negatively correlated to the CEO non-duality (the non-coincidence of the positions of CEO and Chairman of the Board of Directors).

Considering family-controlled companies, the non-coincidence of the positions of $\mathrm{CEO}$ and Chairman of the Board of Directors seems - according to the literature - to be less effective in reducing accounting manipulations, as compared to non-family owned companies, again due to the possible "collusion" between the owner family, board members and management (Prencipe \& Bar-Yosef, 2011).

Therefore, we proceeded to evaluate the following sub-hypothesis:

H2-1: In family-controlled listed companies, the non-coincidence of the two roles, that of CEO and that of Chairman of the Board, has a weaker effect on earnings management than in the whole sample of listed companies.

\section{Methodology}

\subsection{Sample}

To test our hypotheses and sub-hypotheses, we used a sample of industrial, commercial, and service companies listed on the Italian Stock Market over the 2014-2016 period.

Firstly, we eliminated non-Italian companies. Secondly, consistent with Barnhart and Rosenstein (1998), Klein (2002), O'Connell and Cramer (2010) and Peasnell, Pope and Young (2005), we excluded companies from the 
financial and the public utilities sectors because they are subject to a special regulatory environment. Then, we excluded the companies for which the information was not available for the entire time frame of reference. Finally, in order to eliminate disclosures that could affect the statistical validity of the analysis, we did not consider the outliers. The final population was 297 Italian companies listed on the Italian Stock Market over the 2014-2016 period.

Subsequently, to test our sub-hypotheses, we proceeded to the definition of two sub-samples, making a distinction between companies that have or do not have the characteristics of "familiarity". We used the definition of Corbetta and Minichelli (2005), according to which a company is a "family company" if one or several families, hold directly and/or indirectly, at least $50 \%$ of the capital or, despite not having the above share capital, have majority control of it. On the contrary, a company is considered "non-family" if this condition is not fulfilled. Ultimately, 164 family companies and 133 non-family companies are counted for the period 2014-2016.

\subsection{Data}

To test our hypotheses and sub-hypotheses, we used several data sources. Firstly, we hand-collected data regarding corporate governance by analyzing each company's corporate governance reports from 2014 to 2016 . In the case of missing data in either corporate governance reports or the CONSOB database, we analyzed another official source called "Il Calepino dell'Azionista", issued by Mediobanca. Secondly, to distinguish between family and non-family businesses, we hand-collected ownership data from the Commissione Nazionale per le Società e la Borsa (CONSOB) database. Thirdly, to obtain economic and financial data, we used the AIDA database by Bureau van DijK (Moody's Analytics Company). Finally, it is noted that only the dependent variable has been measured also for the year 2013.

\subsection{Variables Measurement}

In order to test the hypotheses and sub-hypotheses underlying the present research, aimed at verifying the capacity of the companies surveyed to use earnings management practices, we first identified and estimated the earnings management variable (dependent variable), which is more suitable for representing the context and the reference sample. Subsequently, the independent and control variables were identified.

\subsection{Dependent Variable}

Consistent with previous studies (Ianniello, 2015; Marra \& al., 2011), the dependent variable is the abnormal working capital accruals (AWCA).

The DeFond and Park model (2001) was used, with a proxy, based on an estimate of the discretionary components of working capital accruals.

According to DeFond and Park (2001), the difference between the working capital such as in the financial statements and the capital that is "expected" or considered "normal", quantified by the estimate parameter defined, identifies the portion of the accrual in the capital (discretionary accrual) which is expected to be written off against profits in following financial years.

As already noted, in this research based on the 2001 Defond \& Park model, a proxy of the aforementioned model was used. Indeed, in order to obtain a better understanding of EM practices, in relation to the Italian context and the available economic and financial data, we used a proxy of the Defond \& Park (2001) model, considering the variables on an annual basis. Therefore, the proxy of the AWCA estimation model used in this study, assumes the following configuration:

$$
\mathrm{AWCA}_{\mathrm{t}}=\mathrm{WC}_{\mathrm{t}}-\left[\left(\mathrm{WC}_{\mathrm{t}-1} / \mathrm{S}_{\mathrm{t}-1}\right) \times \mathrm{S}_{\mathrm{t}}\right]
$$

Where:

$\mathrm{t}$ refers to the current year, $\mathrm{t}-1$ refers to the prior year while $\mathrm{WC}$ is the working capital and $\mathrm{S}$ is the sales.

Ultimately, we used the AWCA in absolute values, since, as in other similar surveys (Ianniello, 2015; Lippolis \& Grimaldi, 2015; Warfield et al., 1995), it detects the use or not of the EM policies.

\subsection{Independent Variables}

The three main explanatory variables are: board of director size, presence of independent directors and Ceo non duality. "Board size" (BOARDS SIZE) is measured as the total number of directors in the board. "Independent directors" (IND) is the percentage of independent/non-executive directors on management boards. Ceo non duality (NO DUAL) is a dummy variable which takes the value of one if it is found that the CEO does not also serve as the Chairman of Board and the value of zero otherwise. IND*NO DUAL is an interaction variable 
representing the joint effects of IND and NO DUAL.

\subsection{Control Variable}

When examining the relationship between BOARD SIZE, IND, NO DUAL, IND*NO DUAL and earnings management, it is necessary to verify other factors that may also influence earnings management. Therefore, in keeping with the prevailing settings and the direct availability and usability, the ROA (return of assets), as measured by income before depreciation divided by fiscal year-end total assets, was taken into consideration (Hsu, 2010; Wintoki, Linck, \& Netter, 2012).

\subsection{The Regression Model}

We developed one model to examine the relationship between earnings management and CDA SIZE, IND, NO DUAL and IND * NO DUAL. In Table 1, we represent variables used and relative measurement and source.

The regression model is structured as follows:

$$
\mathrm{AWCAit}=\beta_{0}+\beta_{1} \mathrm{CDASIZE}+\beta_{2} \mathrm{IND}+\beta_{3} \mathrm{NO} \mathrm{DUAL}+\beta_{4} \mathrm{IND} * \mathrm{NO} \mathrm{DUAL}+\beta 5 \mathrm{ROA}+\mathrm{ut}
$$

Table 1. Variables, measurement and source

\begin{tabular}{|c|c|c|}
\hline Variable & Measurement & Source \\
\hline $\begin{array}{l}\text { AWCA } \\
\text { (dependent) }\end{array}$ & $\begin{array}{l}\text { Proxy of the Defond \& Park model (2001) based on the } \\
\text { calculation of the abnormal accruals of the commercial } \\
\text { working capital of each company }\end{array}$ & AIDA database \\
\hline $\begin{array}{l}\text { CDASIZE } \\
\text { (independent) }\end{array}$ & Total number of directors in the board at the end of each year & $\begin{array}{lr}\text { Hand collection from companies' corporate } \\
\text { governance } & \text { report/CONSOB } \\
\text { database/Calepino } & \text { dell'Azionista } \\
\text { (Mediobanca) } & \end{array}$ \\
\hline $\begin{array}{l}\text { IND } \\
\text { (independent) }\end{array}$ & $\begin{array}{l}\text { Percentage of independent/non-executive directors on the } \\
\text { management boards/boards of directors }\end{array}$ & $\begin{array}{lr}\text { Hand collection from companies' corporate } \\
\text { governance } & \text { report/CONSOB } \\
\text { database/Calepino } & \text { dell'Azionista } \\
\text { (Mediobanca) } & \end{array}$ \\
\hline $\begin{array}{l}\text { NO DUAL } \\
\text { (independent) }\end{array}$ & $\begin{array}{l}\text { Dummy variable which takes the value of one if it found that } \\
\text { the CEO does not also serve as the Chairman of Board (i.e. } \\
\mathrm{CEO} / \mathrm{CM} \text { duality) and the value of zero otherwise }\end{array}$ & $\begin{array}{lr}\text { Hand collection from companies' corporate } \\
\text { governance } & \text { report/CONSOB } \\
\text { database/Calepino } & \text { dell'Azionista } \\
\text { (Mediobanca) } & \end{array}$ \\
\hline $\begin{array}{l}\text { IND*NO } \\
\text { DUAL } \\
\text { (independent) }\end{array}$ & $\begin{array}{l}\text { Interaction variable representing the join effects of variables } \\
\text { IND and NO DUAL }\end{array}$ & $\begin{array}{lr}\text { Hand collection from companies' corporate } \\
\text { governance } & \text { report/CONSOB } \\
\text { database/Calepino } & \text { dell'Azionista } \\
\text { (Mediobanca) } & \end{array}$ \\
\hline $\begin{array}{l}\text { ROA } \\
\text { (control) }\end{array}$ & $\begin{array}{l}\text { Income before depreciation divided by fiscal year-end total } \\
\text { assets }\end{array}$ & AIDA database \\
\hline
\end{tabular}

\section{Empirical Results}

\subsection{Univariate Analysis}

In this section, differences in earnings management activities between the whole sample of Italian listed companies and the sub-sample of family companies are investigated. Tables 2 (whole sample) e 3 (sub sample of family companies) shows two correlation matrixes of the variables used in the model.

Table 2. Pearson correlation matrix - Whole sample $(\mathrm{N}=297)$

\begin{tabular}{lllllll}
\hline & AWCA & FAM50 & CDA SIZE & IND & $\begin{array}{l}\text { NO } \\
\text { DUAL }\end{array}$ & ROA \\
\hline AWCA & 1.0000 & & & & & \\
FAM50 & -0.0545 & 1.0000 & & & & \\
CDASIZE & -0.0499 & 0.0233 & 1.0000 & & & \\
IND & -0.0715 & -0.1762 & 0.2902 & 1.0000 & & \\
NODUAL & -0.0289 & -0.0148 & 0.3696 & 0.2593 & 1.0000 & \\
ROA & -0.1871 & 0.0220 & -0.0545 & -0.0671 & -0.0467 & 1.0000 \\
\hline
\end{tabular}


Table 3. Pearson correlation matrix - family-controlled companies $(\mathrm{N}=164)$

\begin{tabular}{llllll}
\hline & AWCA & CDA SIZE & IND & NO DUAL & ROA \\
\hline AWCA & 1.0000 & & & & \\
CDASIZE & -0.0142 & 1.0000 & & & \\
IND & -0.0213 & 0.3043 & 1.0000 & & \\
NODUAL & -0.0044 & 0.3740 & 0.1188 & 1.0000 & \\
ROA & -0.2309 & -0.0332 & 0.0262 & 0.0845 & 1.0000 \\
\hline
\end{tabular}

With reference to the number of board members (CDA SIZE), it is noted that, in accordance with expectations, the correlation with earnings management measures is negative, but not very relevant in either sample.

The correlation analysis, indeed, shows that, in both samples, AWCA is also negatively related to IND, in accordance with expectations.

With reference to the non-coincidence of the two top figures - that of CEO and that of Chairman of the Board of Directors, it is noted, as foreseen, that the correlation with earnings management practices is negative in both samples. From a comparative perspective, it is possible to observe how this characterization of governance produces a minor effect on the intensity of earnings management policies (-0.0044) in family businesses as compared to the total number of companies in the sample (-0.0289). Finally, it is observed that AWCA is also negatively related to companies' ROA, in both samples examined.

\subsection{Multivariate Analysis: Results and Discussion}

In order to test the hypotheses, a regression analysis was performed in which the earnings management measure was used as a dependent variable. The size of the Board, the percentage of independent directors on the Board, the CEO non-duality and the product of IND and NO DUAL are the independent variables. In particular, the variable IND * NODUAL represents the so-called interaction term and is useful for estimating the possible effects of interaction between independent variables within the general model (Agresti \& Finlay, 2009). From a statistical point of view this interaction appears to be symmetrical, that is, the effect of one changes with the other and vice versa. The ROA index was also taken into consideration as a model control variable.

Table 4. Regression model - whole sample ( $\mathrm{N}=297)$

\begin{tabular}{llcll}
\hline & Expected sign & Coefficient & Std. Error & p-value \\
\hline INTERCEPT & & 0.135183 & 0.542680 & $0.013294^{*}$ \\
CDA SIZE & $(?)$ & -0.005460 & 0.004359 & 0.211397 \\
IND & $(-)$ & -0.002635 & 0.001305 & $0.044472 *$ \\
NO DUAL & $(+)$ & 0.066206 & 0.060483 & 0.274593 \\
IND * NO DUAL & $(-)$ & -0.002211 & 0.001507 & 0.143484 \\
ROA & $(-)$ & -0.008000 & 0.002421 & $0.000914^{* * *}$ \\
\hline
\end{tabular}

Note. Significance levels: ‘***’ $0.001 ;$ ‘**’ $0.01 ;$ ‘*’ 0.05 .

The variables are defined in Table 4 and with reference to the general hypotheses, we expect a negative coefficient for IND and for NO DUAL and, consequently, a negative coefficient for the interaction between the two variables (IND * NO DUAL).

To test the sub-hypotheses, a second regression analysis was performed with reference to the subsample of the family-controlled companies. The earnings management measure was also used as the dependent variable in this second analysis. The size of the Board, the percentage of independent directors on the Board, the CEO non-duality and the interaction of the two variables IND and NO DUAL are the independent variables. The ROA index was also taken into consideration as a model control variable. 
Table 5. Regression model - family-controlled companies $(\mathrm{N}=164)$

\begin{tabular}{llccc}
\hline & Expected sign & Coefficient & Std. Error & p-value \\
\hline INTERCEPT & & 0.1937996 & 0.0721849 & $0.00803 * *$ \\
CDA SIZE & $(?)$ & -0.0019536 & 0.0060420 & 0.74687 \\
IND & $(-)$ & -0.0005213 & 0.0017424 & 0.76520 \\
NO DUAL & $(-)$ & 0.0109168 & 0.0834618 & 0.89610 \\
IND * NO DUAL & $(-)$ & -0.0006165 & 0.0021380 & 0.77344 \\
ROA & $(-)$ & -0.0090763 & 0.0030323 & $0.00320 * *$ \\
\hline
\end{tabular}

Note. Significance levels: ‘***’ 0.001 ; ‘**’ 0.01 ; ‘*’ 0.05 .

The IND variable, i.e. the percentage of independent directors on the Board, presents a negative coefficient, consistent with expectations. However, it should be noted that this value is equal to 0.002625 , with a significance level of $1 \%$. This indicates that, in effect, the percentage of independent directors on the Board of Directors has a very mild influence on the Board's monitoring capacity with reference to the prevention of the use of earnings management practices.

Looking specifically at the family-controlled companies (Table 5), the IND variable shows a negative coefficient, as noted with reference to the whole sample. However, it appears to have a much lower effect on the magnitude of earnings than the whole sample observed, suggesting that - according to Prencipe and Bar-Yosef (2011) - in family controlled companies the percentage of independents on the Board is actually less effective in reducing earnings management practices, as highlighted, moreover, by the value of the estimated coefficient.

As regards the NO DUAL variable - with reference to the second general hypothesis, dealing with the whole sample - the coefficient turns out to be positive, but statistically irrelevant. Since the coefficient does not appear to be statistically significant, there is no possibility to affirm with an inferential approach but with a descriptive one, whether non-coincidence of the offices - that of Chairman of the Board and that of CEO - reduces the probability that earnings management will be put into practice. In light of this, and according to Marra (2013) and Lippolis and Grimaldi (2015), the separation of the figures of Ceo and Chairman, does not appear to be crucial in limiting earnings management.

Even when analyzing family-controlled companies, the results do not clearly express whether and to what extent the separation of roles is effective in limiting earnings management. The coefficient, in fact, turns out to be negative, but not statistically significant, thus providing interesting findings only by a descriptive point of view.

With regard, therefore, to the ability of the Board to safeguard the quality of financial reporting, the survey shows that the percentage of independent directors on the Board do not represent - as instead in other contexts - a factor that contributes to earnings quality. These results can be interpreted in the light of the significant presence of family-owned companies and in the light of the role of the Corporate Governance Code of listed companies. In particular, analyzing the results of the first sub-hypothesis, it should be noted that the lower effect of the independence, on the magnitude of earnings in family companies is attributable to the fact that the reference family is able to influence the appointment of directors, including so called independents, on the basis of personal ties: therefore in such companies the presence of independent directors does not increase the quality of financial reporting.

With reference to the CEO duality, it should be noted that in family companies the CEO is an expression of the family and the same role as Chairman is not usually held by an independent, but he represents directly or indirectly the controlling shareholder or belongs to the reference family. This suggests that the choices related to the earnings management policies are however attributable to the family, regardless of the person who holds the role of CEO and Chairman.

In general terms it is useful to remember that the Corporate Governance Code provides application criteria, (based on comply or explain principle) and not peremptory, necessary to assess the independence of the board. The same application of this requirement, thus, is declined differently in the different Boards of directors.

\section{Conclusion}

The aim of the research is to investigate the influence of some characteristics that define the independence of the Board of directors on earnings management policies among a sample of Italian listed companies over the period from 2014 to 2016.

With reference to each of the characteristics examined, general hypotheses have been formulated, i.e. referring to 
the whole sample of listed companies analyzed, and specific hypotheses, with particular reference to listed companies with family control.

The comparison between the two samples made it possible to observe, the degree of effectiveness of the monitoring mechanisms of the Board of Directors' activity (board size, independence of the board and duality of the CEO) within each sample.

In particular, with regard to the ability of the Board to safeguard the quality of financial reporting, the survey shows that the percentage of independent directors in the Boards does not represent a factor that contributes to earnings quality, specifically in the family companies sample.

The non-coincidence of the figures of CEO and Chairman, instead, does not appear to be relevant in limiting earnings management in the subsample.

These results suggest that the presence of the family limits the board effectiveness in monitoring the earnings management practices.

However, although the research offers several insights into the relationship examined, some limitations should be highlighted. First, it would be interesting to analyze different country contexts, attributable to corporate governance models other than the Italian one. Secondly, with reference to Italian institutional context, it would be interesting to study and compare different institutional situations, such as Italian non-listed companies. Finally, using the same samples and the same analysis model of this research, it would be interesting include some qualitative characteristics of each independent board member.

This research uncovers some interesting results that have implications for both scholars and practitioners with an interest in earnings management and corporate governance issues.

First, the research represents one of the few studies concerning the Italian context with its peculiarities, considering the earnings management issue in companies with a high concentration of family ownership, characterized by different type of agency problems.

Secondly, this study aims to further stimulate the debate on the most effective features of structure and composition of the Board of Directors in family-controlled companies: specifically, the conclusions could lead to a reconsideration of the validity of certain characters of the boards that defines independence, when referred to these companies.

This research, indeed, points at some interesting paths for future research. A valuable contribution for examining the relationship between corporate governance and earnings management practices, could result from a qualitative study which includes the study of process variables to explain board behaviour in family-controlled companies.

\section{References}

Achleitner, A., Fichtl, N., Kaserer, C., \& Siciliano, G. (2014). Real Earnings Management and Accrual-based Earnings Management in Family Firms. European Accounting Review, 23(3), 431-461. https://doi.org/10.1080/09638180.2014.895620

Agresti, A., \& Finlay, B. (2009). Statistical methods for the social sciences. New York, NY: Pearson Prentice Hall.

Ali, A., Chen, T. Y., \& Radhakrishnan, S. (2007). Corporate disclosures by family firms. Journal of Accounting and Economics, 44(1-2), 238-286. https://doi.org/10.1016/j.jacceco.2007.01.006

Alves, S. (2012). Ownership Structure and Earnings Management: Evidence from Portugal. Australasian Accounting Business and Finance Journal, 6(1), 57-74. Retrieved from $\mathrm{https} / / /$ ro.uow.edu.au/cgi/viewcontent.cgi?article $=1278 \&$ context=aabfj

Barca, G. (1996). On corporate governance in Italy: Issues, facts and agenda. Retrieved from https://www.researchgate.net/publication/247000705_On_Corporate_Governance_in_Italy_Issues_Facts_an d_Agenda

Barnhart, W. S., \& Rosenstein, S. (1998). Board composition, managerial ownership, and firm performance: an empirical analysis. The Financial Review, 33(4), 1-16. https://doi.org/10.1111/j.1540-6288.1998.tb01393.x

Beasley, M. (1996). An empirical analysis of the relation between the board of director composition and the financial statement fraud. The Accounting Review, 71(4), 443-465.

Cascino, S., Pugliese, A., Mussolino, D., \& Sansone, C. (2010). The influence of family ownership on the 
Quality of Accounting Information. Family Business Review, 23(3), 246-265. https://doi.org/10.1177/0894486510374302

Consob. (2018). Report on corporate governance of Italian listed company. Roma: Consob. Retrieved from http://www.consob.it/documents/46180/46181/rcg2018.pdf/549286f4-907e-427c-9fdf-926386140479

Corbetta, G. (1995). Il caso italiano tra capitalismo familiare e mercato. In G. Airoldi, F. Amatori, \& G. Invernizzi (Eds.), Proprietà e governo delle aziende italiane. Milano, IT: Egea.

Corbetta, G., \& Minichilli, A. (2005). Il governo delle imprese italiane quotate a controllo familiare: i risultati di una ricerca esplorativa. Economia \& Management, 6, 59-77.

Dechow, P. M., Richardson, S. A., \& Tuna, I. (n.d.). Why Are Earnings Kinky? An Examination of the Earnings Management Explanation. Review of Accounting Studies, 8, 355-384. https://doi.org/10.1023/A:1024481916719

Dechow, P. M., Sloan, R. G., \& Sweeney, A. P. (1995). Detecting Earnings Management. The Accounting Review, $70(2), 193-225$

Dechow, P. M., Sloan, R. G., \& Sweeney, A. P. (1996). Causes and consequences of earnings manipulation: An analysis of firms subject to enforcement actions by the SEC. Contemporary Accounting Research, 13(1), 1-36. https://doi.org/10.1111/j.1911-3846.1996.tb00489.x

DeFond, M. L., \& Park, C. W. (2001). The reversal of abnormal accruals and the market valuation of earnings surprises, The Accounting Review, 76(3), 375-404. https://doi.org/10.2308/accr.2001.76.3.375

Di Donato, F. (2012). Gli amministratori indipendenti: Corporate governance, Earnings management. Roma, IT: Luiss University Press.

González, J. S., \& Garcìa, E. (2014). Does Corporate Governance Influence Earnings Management in Latin American Markets? Journal of Business Ethics, 121, 419-440. https://doi.org/10.1007/s10551-013-1700-8

Grimaldi, F., \& Lippolis, S. (2019). Ownership structure and control models in Italian Listed Companies. In A.N. Kostyuk M.Tutino S. Prigge et Al.. (Eds.), Corporate ownership and control: international trends (pp. 33-48). Sumy, UKR: Virtus Inter Press.

Hsu, H. E. (2010). The relationship between board characteristics and financial performance: An empirical study of United States initial public offerings. International Journal of Management, 27(2), 332-341.

Ianniello, G. (2015). The effects of board and auditor independence on earnings quality: Evidence from Italy. Journal of Management and Governance, 19(1), 229-253. https://doi.org/10.1007/s10997-013-9285-2

Jensen, M. C. (1993). The Modern Industrial Revolution, Exit, and the Failure of Internal Control Systems. The Journal of Finance, 48(3), 831-880. https://doi.org/10.1111/j.1540-6261.1993.tb04022.x

Kao, L., \& Chen, A. (2004). The effects of board characteristics on earnings management. Corporate Ownership and Control, 1(3), 96-107. http://doi.org/10.22495/cocv1i3p9

Klein, A. (2002). Audit Committee, Board of Director Characteristics and Earnings Management. Journal of Accounting and Economics, 33(3), 375-400. https://doi.org/10.1016/S0165-4101(02)00059-9

Lippolis, S., \& Grimaldi, F. (2015). Corporate governance e politiche di Earnings Management. Aspetti teorici ed evidenze empiriche. Milano, IT: FrancoAngeli.

Magli, F., \& Nobolo, A. (2013). Corporate governance and control in Italian family business: An empirical analysis. In EBES (Eds.), EBES 2013 Anthology (pp. 71-91). Rome, Italy: Faculty of Economics of Sapienza.

Marra, A. (2013). Consigli di amministrazione e qualità degli utili in Italia. Milano, IT: Egea.

Marra, A., Mazzola, P., \& Prencipe, A. (2011). Board Monitoring and Earnings Management: Pre- and Post-IFRS. International Journal of Accounting, 46(2), 205-230. https://doi.org/10.1016/j.intacc.2011.04.00

Melis, A. (1999). Corporate governance. Torino, IT: Giappichelli.

Melis, A. (2000). Corporate governance in Italy. Corporate Governance: An International Review, 8(4), $347-355$. https://doi.org/10.1111/1467-8683.00213

O’Connell, V., \& Cramer, N. (2010). The relationship between firm performance and board characteristics in Ireland. European Management Journal, 28(5), 387-399. https://doi.org/10.1016/j.emj.2009.11.002

Park, Y. W., \& Shin, H. H. (2004). Board composition and earnings management in Canada. Journal of 
Corporate Finance, 10(3), 431-457. http://dx.doi.org/10.1016/s0929-1199(03)00025-7

Peasnell, K. V., Pope, P. F., \& Young, S. (2005). Boards Monitoring and Earnings Management: Do Outside Directors Influence Abnormal Accruals? Journal of Business, Finance and Accounting, 32(7-8), 1311-1346. https://doi.org/10.1111/j.0306-686X.2005.00630.x

Prencipe, A., \& Bar-Yosef, S. (2011). Corporate governance and earnings management in family-controlled companies. Journal of Accounting, Auditing and Finance, 26(2), 199-227. https://doi.org/10.1177/0148558X11401212

Schulze, W. S., Lubatkin, M. H., Dino, R. N., \& Buchholz, A. K. (2001). Agency relationships in family firms: Theory and evidence. Organization Science, 12(2), 99-116. http://dx.doi.org/10.1287/orsc.12.2.99.10114

Tiscini, R. (2008). Le aziende di famiglia "quotate". Teoria del governo d'impresa. Roma, IT: Luiss University Press.

Tiscini, R., \& Di Donato, F. (2008). The Impact of Family Control and Corporate Governance Practices on Earnings Quality of Listed Companies: A Study of the Italian Case. Retrieved from https://papers.ssrn.com/sol3/papers.cfm?abstract_id=1346457

Wang, D. (2006). Founding family ownership and earnings quality. Journal of Accounting Research, 44(3), 619-656. https://doi.org/10.1111/j.1475-679X.2006.00213.x

Warfield, T. D., Wild, J. J., \& Wild, K. L. (1995). Managerial ownership accounting choices, and informativeness of earnings. Journal of Accounting and Economics, 20(1), 61-91. https://doi.org/10.1016/0165-4101(94)00393-J

Watts, R., \& Zimmerman, J. (1978). Towards a Positive Theory of the Determination of Accounting Standards. The Accounting Review, 53(1), 112-134.

Wintoki, M. B., Linck, J. S., \& Netter, J. M. (2012). Endogeneity and the dynamics of internal corporate governance. Journal of Financial Economics, 105(3), 581-606. https://doi.org/10.1016/j.jfineco.2012.03.005

Xie, B., Davidson, W., \& DaDalt, P. J. (2003). Earnings management and corporate Governance. The role of the board and the Audit Committee. Journal of Corporate Finance, 9(3), 295-316. https://doi.org/10.1016/S0929-1199(02)00006-8

Zattoni, A. (2019). The evolution of corporate governance in Italy: formal convergence or path-dependence? Corporate Governance and Research \& Development Studies, 1, 13-35. https://doi.org/10.3280/cgrds1-2019oa8799

\section{Copyrights}

Copyright for this article is retained by the author(s), with first publication rights granted to the journal.

This is an open-access article distributed under the terms and conditions of the Creative Commons Attribution license (http://creativecommons.org/licenses/by/4.0/). 